\title{
A note on the effect of caprylic acid and triacylglycerols of caprylic and capric acid on growth rate and shedding of coccidia oocysts in weaned piglets*
}

\author{
M. Marounek ${ }^{1,2,4}$, E. Skřivanová ${ }^{2,3}$ and V. Skřivanová ${ }^{2}$ \\ ${ }^{1}$ Institute of Animal Physiology and Genetics, Czech Academy of Sciences \\ CZ-142 20 Praha 4, Czech Republic \\ ${ }^{2}$ Research Institute of Animal Production, Uhřiněves \\ CZ-104 01 Praha 10, Czech Republic \\ ${ }^{3}$ Department of Nutrition, Dietetics, Zoohygiene and Plant Products, \\ University of Veterinary and Pharmaceutical Sciences Brno \\ CZ-612 42 Brno, Czech Republic
}

(Received 28 November 2003; revised version 20 February 2004; accepted 9 April 2004)

\begin{abstract}
Medium-chain fatty acids (MCFA) are efficient antimicrobial compounds. The aim of this study was to evaluate the effect of caprylic acid (C8:0), and an oil containing triacylglycerols of caprylic and capric acid (C10:0), on growth rate of piglets and shedding of coccidia oocysts. Piglets, weaned at 28-32 days of age, were fed a basal diet (Group 1), the same diet supplemented with caprylic acid at $5 \mathrm{~g} / \mathrm{kg}$ (Group 2), or supplemented with the MCFA-containing oil at $10 \mathrm{~g} / \mathrm{kg}$ (Group 3). The experiment was carried out on a commercial farm and lasted for 3 weeks. In the course of this period piglets of groups 1, 2 and 3 gained on average $3.64,4.98$ and $3.95 \mathrm{~kg}$, respectively. The effect of caprylic acid on weight gains was statistically significant $(\mathrm{P}<0.05)$. Almost all piglets were infected with Cryptosporidium parvum and some of them also with Isospora suis. In treated piglets, shedding of cryptosporidial oocysts was one week delayed and the patent period was shorter. This suggests that a certain coccidiostatic effect of MCFA exists.
\end{abstract}

KEY WORDS: piglets, caprylic acid, capric acid, weight gain, coccidia

\footnotetext{
${ }^{*}$ Supported by the Academy of Sciences of the Czech Republic, Grant No. S5045317

${ }^{4}$ Corresponding author: e-mail: marounek@iapg.cas.cz
} 


\section{INTRODUCTION}

There has been an increasing interest in the last decade in research of antimicrobial agents capable to replace non-therapeutical antibiotics in animal feed. Fatty acids belong to candidate replacements for antibiotics. Nieman (1954) and Kabara et al. (1972) concluded that $(i)$ antimicrobial effect of unsaturated fatty acids was more pronounced than that of saturated fatty acids, and (ii) medium-chain fatty acids (MCFA) were more efficient antimicrobials than other saturated fatty acids. Unsaturated fatty acids, however, are not suitable feed additives due to their susceptibility to oxidation. We showed in a recent study that caprylic and capric acid were active against both gram-positive and gram-negative bacteria from the rumen and rabbit caecum (Marounek et al., 2002a), and against common enteropathogenic bacteria (Marounek et al., 2002b). Caprylic acid added at $0.5 \%$ to a granulated feed of growing rabbits significantly decreased mortality from 16.7 to $0 \%$, but had no significant effect on total weight gain and feed conversion (Skřivanová and Marounek, 2002). The purpose of the present study was to perform similar experiments with weaned piglets. Effect of caprylic acid was compared with effect of a commercially available oil containing triacylglycerols of caprylic and capric acid. Both MCFA and their triacylglycerols have already been tested in pigs. Cera et al. (1989) added a mixture of caprylic and capric acid to a diet of weaned pigs at 80 $\mathrm{g} / \mathrm{kg}$. This treatment nonsignificantly increased weight gains of piglets from 0.32 to $0.34 \mathrm{~kg}$. There was, however, no antibiotic-free control in this trial. Newport et al. (1979) found no significant effect of triacylglycerols of MCFA on growth rate of piglets fed a milk substitute. On the other hand, Dierick et al. (2002) reported a significant increase of growth rate of weaned piglets fed a diet supplemented with an oil containing triacylglycerols of MCFA, with or without an exogenous lipase. The same authors reported a $25 \%$ increase of growth gains of piglets fed a diet with MCFA-containing seeds of Cuphea lanceolata and Cuphea ignea, in comparison with the control (Dierick et al., 2003). No information is available on effect of MCFA against parasitic protozoa in the animal digestive tract. Ruminal studies, however, showed a significant antiprotozoal effect of MCFA (Matsumoto et al., 1991; Dohme et al., 2001).

\section{MATERIAL AND METHODS}

\section{Animals, management and diets}

One hundred and twenty crossbred piglets (Czech White x Landrace), weaned at 28-32 days of age were allotted to one of three dietary treatments based on initial weight, sex and litter. Piglets were housed in an environmentally controlled nursery, 
in 6 pens ( 2 pens per treatment) with 20 piglets in each. Diets and water were available ad libitum. Piglets of the group 1 were fed a basal diet (Table 1).

TABLE 1

Ingredients and analysed chemical composition of the basal diet

\begin{tabular}{lllr}
\hline $\begin{array}{l}\text { Ingredients } \\
\%\end{array}$ & \multicolumn{3}{c}{$\begin{array}{c}\text { Composition } \\
\mathrm{g} / \mathrm{kg}\end{array}$} \\
\hline Barley & 35 & Dry matter & 882 \\
Wheat & 36 & Crude protein & 199 \\
Soyabean meal (extracted) & 12 & Crude fat & 75 \\
Soyabean protein concentrate & 5.6 & Crude fibre & 33 \\
Grease & 3 & Starch & 446 \\
Dried yeast & 2 & NSP & 79 \\
Soya oil & 1.3 & Ash & 50 \\
Monocalcium phosphate & 1.4 & & \\
Limestone & 1 & & \\
Salt & 0.47 & & \\
Threonine & 0.70 & & \\
Lysine.HCl & 0.60 & & \\
Tryptophan & 0.22 & & \\
Methionine & 0.11 & & \\
Vitamin, trace mineral premix & 0.60 & & \\
\hline
\end{tabular}

Piglets of the group 2 were fed the same diet supplemented with caprylic acid (Fluka) at $5 \mathrm{~g} / \mathrm{kg}$. Piglets of the group 3 were fed the basal diet supplemented with Akomed R (Karlshamns, Sweden) at $10 \mathrm{~g} / \mathrm{kg}$. Akomed R contains caprylic, capric and lauric acid at $60.8,38.7$ and $0.3 \mathrm{~g}$ per $100 \mathrm{~g}$ fatty acid methyl esters, respectively. Soya oil concentration in the feed of piglets of the group 2 and 3 was correspondingly decreased. The weights of individual piglets were recorded weekly. Faeces of five piglets in each pen were collected once a week and examined for the presence of coccidia. The experiment lasted for 3 weeks.

\section{Analyses and statistics}

Concentration of protein, fat and fibre in the feed was determined using Kjeltec Auto 1030 Analyser, Soxtec 1043 and Fibertec 2010 from Tecator AB Comp. (Sweden) equipments, respectively. Dry matter, starch and ash contents were determined by standard AOAC (1980) procedures.

Oocysts of coccidia were counted using a standard sugar flotation technique (sp. gr. 1.27). All counting was performed by the same individual. Numbers of oocysts present were scored on a five point scale: (0) no oocysts found, (1) 1-2 oocysts per microscopic field at $\times 450$ magnification in 10-times diluted samples, 
(2) 3-6 oocysts per field, (3) 7-10 oocysts per field, and (4) more than 10 oocysts per field.

Analysis of variance was used to evaluate the effect of caprylic acid and Akomed R on weight gains and intensity of oocyst shedding in piglets. Comparison of means was done by the Tukey t-test, where appropriate.

\section{RESULTS}

Control piglets gained $3.64 \pm 0.43 \mathrm{~kg}$ in the course of the experiment (Table 2). Weight gains of piglets fed the diet with $0.5 \%$ caprylic acid were significantly higher $(4.97 \pm 0.36 \mathrm{~kg})$, whereas gains of piglets fed the diet with the MCFAcontaining oil were not significantly different from those of piglets of the control group.

TABLE 2

Effect of caprylic acid and oil containing triacylglycerols of caprylic and capric acid on performance of piglets $^{1}$

\begin{tabular}{lccc}
\hline & \multicolumn{3}{c}{ Treatment group } \\
\cline { 2 - 4 } & control & caprylic acid & MCFA-containing oil \\
\hline Number of piglets & 40 & 40 & 40 \\
Initial liveweight, $\mathrm{kg}$ & $8.28 \pm 0.18^{\mathrm{a}}$ & $8.28 \pm 0.15^{\mathrm{a}}$ & $7.69 \pm 0.21^{\mathrm{a}}$ \\
& & & \\
Weight gain, kg & & & \\
$\quad 1^{\text {st }}$ wk $^{2}$ & $0.51 \pm 0.15^{\mathrm{a}}$ & $0.36 \pm 0.13^{\mathrm{a}}$ & $0.58 \pm 0.14^{\mathrm{a}}$ \\
$2^{\text {nd }}$ wk $^{2}$ & $1.50 \pm 0.14^{\mathrm{a}}$ & $1.93 \pm 0.13^{\mathrm{a}}$ & $1.59 \pm 0.14^{\mathrm{a}}$ \\
$3^{\text {rd }}$ wk $^{2}$ & $1.63 \pm 0.31^{\mathrm{a}}$ & $2.68 \pm 0.17^{\mathrm{b}}$ & $1.78 \pm 0.18^{\mathrm{a}}$ \\
$1^{\text {st }} 3^{\text {rd }}$ wk $^{2}$ & $3.64 \pm 0.43^{\mathrm{a}}$ & $4.97 \pm 0.36^{\mathrm{b}}$ & $3.95 \pm 0.35^{\mathrm{ab}}$ \\
Final liveweight, $\mathrm{kg}$ & $11.92 \pm 0.41^{\mathrm{a}}$ & $13.25 \pm 0.35^{\mathrm{b}}$ & $11.64 \pm 0.42^{\mathrm{a}}$ \\
\hline
\end{tabular}

means \pm SEM

${ }^{1}$ weaned at $4 \mathrm{wk}$ of age

${ }^{2}$ after weaning

${ }^{\mathrm{ab}}$ values in the same row with different superscripts differ at $\mathrm{P}<0.05$

Almost all piglets were spontaneously infected with Cryptosporidium parvum one week (control) or two weeks (treated groups) after weaning (Table 3). The most intensive shedding of oocysts was observed in control piglets, two weeks after weaning. Differences, however, did not reach the statistical significancy $(\mathrm{P}=0.096)$, and ceased later. Four, five and seven piglets in the group 1, 2 and 3, respectively, were infected also with Isospora suis. The intensity of infection by this parasite, however, was very low. No Eimeria oocysts were observed in faeces of piglets in this experiment. 
TABLE 3

Occurence of Cryptosporidium parvum oocysts in faeces of piglets fed basal diet (control) or diets supplemented with caprylic acid and oil containing triacylglycerols of caprylic and capric acid

\begin{tabular}{cccc}
\hline Week $^{1}$ & \multicolumn{3}{c}{ Treatment group } \\
\cline { 2 - 4 } & control & caprylic acid & MCFA-containing oil \\
\hline 0 & 0 & 0 & 0 \\
1 & $0.90 \pm 0.52$ & 0 & 0 \\
2 & $2.10 \pm 0.48$ & $1.30 \pm 0.34$ & $1.20 \pm 0.39$ \\
3 & $0.60 \pm 0.16$ & $0.50 \pm 0.17$ & $0.60 \pm 0.16$ \\
\hline
\end{tabular}

means \pm SEM

${ }^{1}$ after weaning

0 - no oocyst observed; 1 - sporadic occurence of oocysts; 2 - fairly numerous oocysts; 3 - numerous oocysts

\section{DISCUSSION}

Organic acids are well-tried performance enhancers in pigs (reviewed by Partanen and Mroz, 1999). After ingestion, organic acids reduce the total microbial load in the upper digestive tract and increase digestibility of nutrients (reviewed by Dibner and Buttin, 2002). Our results are in line with those of Dierick et al. $(2002,2003)$. Piglets on the diet supplemented with caprylic acid gained more than those on the control diet (237 vs $173 \mathrm{~g} /$ day). This difference was greater than we had expected. In our opinion, it may be related to the fact that nutritional responses of pigs to antimicrobials are clearly sensitive to environmental influence, being much higher in farm tests than in research stations (Rosen, 1995). Poorer growth rate of piglets on the diet with the esters of caprylic and capric acid present in Akomed R indicates the need of exogenous lipase supplementation (see also Dierick et al., 2002, 2003).

Shedding of Cryptosporidium oocysts was one week delayed and less intensive in both treated groups than in control piglets. Unfortunately, the use of a scoring system rather than precise oocysts counting makes an exact statistical evaluation of findings difficult.

\section{REFERENCES}

AOAC, 1980. Official Methods of Analysis, Association of Official Analytical Chemists. $13^{\text {th }}$ Edition. Washington, DC

Cera K.R., Mahan D.C., Reinhart G.A., 1989. Postweaning swine performance and serum profile responses to supplemental medium-chain free fatty acids and tallow. J. Anim. Sci. 67, 2048-2055

Dibner J.J., Buttin P., 2002. Use of organic acids as a model to study the impact of gut microflora on nutrition and metabolism. J. Appl. Poultry Res. 11, 453-463

Dierick N.A., Decuypere J.A., Degeyter I., 2003. The combined use of whole Cuphea seeds containing medium chain fatty acids and an exogenous lipase in piglet nutrition. Arch. Anim. Nutr. 57, 49-63 
Dierick N.A., Decuypere J.A., Molly K., Van Beek E., Vanderbeke E., 2002. The combined use of triacylglycerols containing medium-chain fatty acids (MCFAs) and exogenous lipolytic enzymes as an alternative for nutritional antibiotics in piglet nutrition II. In vivo release of MCFAs in gastric cannulated and slaughtered piglets by endogenous and exogenous lipases; effects on the luminal gut flora and growth performance. Livest. Prod. Sci. 76, 1-16

Dohme F., Machmüller A., Wasserfallen A., Kreuzer M., 2001. Ruminal methanogenesis as influenced by individual fatty acids supplemented to complete ruminal diets. Lett. Appl. Microbiol. 32, 47-51

Kabara J.J., Swieczkowski D.M., Conley A.J., Truant J.P., 1972. Fatty acids and derivatives as antimicrobial agents. Antimicrob. Agents Chemother. 2, 23-28

Marounek M., Skřivanová V., Savka O.G., 2002a. Effect of caprylic, capric and oleic acid on growth of rumen and rabbit caecal bacteria. J. Anim. Feed Sci. 11, 507-516.

Marounek M., Skřivanová V., Savka O.G., 2002b. Antimicrobial effect of $\mathrm{C}_{2}-\mathrm{C}_{18}$ fatty acids on Escherichia coli, clostridia and salmonellas. Proceedings of the WG1 and WG4 Joint COST Action 848-ECVAM Meeting. JRC Ispra, Varese (Italy), p.36

Matsumoto M., Kobayashi T., Takenaka A., Itabashi H., 1991. Defaunation effects of medium-chain fatty acids and their derivatives on goat rumen protozoa. J. Gen. Appl. Microbiol. (Tokyo) 37, 439-445

Newport M.J., Storry J.E., Tuckley B., 1979. Artificial rearing of pigs. 7. Medium chain triglycerides as a dietary source of energy and their effect on live-weight gain, feed: gain ratio, carcass composition and blood lipids. Brit. J. Nutr. 41, 85-93

Nieman C., 1954. Influence of trace amounts of fatty acids on the growth of microorganisms. Bacteriol. Rev. 18, 147-163

Partanen K.H., Mroz Z., 1999. Organic acids for performance enhancement in pig diets. Nutr. Res. Rev. 12, 117-145

Rosen G.D., 1995. Antibacterials in poultry and pig nutrition. In: R.J. Wallace, A. Chesson (Editors). Biotechnology in Animal Feeds and Animal Feeding. VCH Verlagsgesellschaft mbH, Weinheim (Germany), pp. 143-172

Skřivanová V., Marounek M., 2002. Effects of caprylic acid on performance and mortality of growing rabbits. Acta Vet. Brno 71, 435-439

\section{STRESZCZENIE}

\section{Wpływ dodatku kwasu kaprylowego i trójgliceroli kwasów kaprylowego i kaprynowego na tempo wzrostu i wydalanie oocyst kokcidiów przez odsadzone prosięta}

Średnio-łańcuchowe kwasy tłuszczowe (MCFA) są skutecznymi związkami przeciwbakteryjnymi. Celem badań była ocena wpływu kwasu kaprylowego (C8:0) oraz oleju zawierającego trójglicerole kwasów kaprylowego i kaprynowego (C10:0) na tempo wzrostu prosiąt oraz wydalanie oocyst kokcidiów. Doświadczenie przeprowadzono na fermie towarowej. Prosięta, odsadzone w wieku 28-32 dni, otrzymywały przez 3 tygodnie dawkę podstawową (grupa 1), dietę podstawową z dodatkiem kwasu kaprylowego w ilości $5 \mathrm{~g} / \mathrm{kg}$ (grupa 2) lub z dodatkiem oleju zawierającego MCFA w ilości $10 \mathrm{~g} / \mathrm{kg}$ (grupa 3). Prosięta przyrosły w tym czasie średnio po 3,64; 4,98 i 3,95 kg, odpowiednio w grupach 1, 2 i 3 . Wpływ dodatku kwasu kaprylowego na przyrosty był istotny $(\mathrm{P}<0,05)$. Prawie wszystkie prosięta były zakażone Cryptosporidium parvum, a niektóre z nich także Isospora suis. U prosiąt otrzymujących dodatek kwasów wydalanie kryptosporidalnych form oocytów było opóźnione o tydzień i przez krótszy okres w porównaniu z prosiętami grupy kontrolnej.

Na podstawie otrzymanych wyników można sądzić, że MCFA mają pewne działanie kokcidiostatyczne. 